\title{
PENEGAKAN HUKUM NETRALITAS PEGAWAI NEGERI SIPIL (PNS)
}

\author{
Oleh: \\ Sri Hartini \\ Fakultas Hukum Universitas Jenderal Soedirman Purwokerto \\ E-mail: hartinimustika@gmail.com
}

\begin{abstract}
Basically, the substance of democracy is the existence of role/active participation in the governance based on independence, equality and freedom. Somehow in new era, this strategic position of public servant was used by political party which finally makes political problems in the conception of law enforcement and makes confusedness to the role of public servant. Finally, the government make coherent regulation concerning with the neutrality in the public service law. Arrangement of public service neutrality, arranged in article 3 sentence (2) and sentence (3) Law No. 43 Year 1999 and Government Regulation No. 37 Year 2004 concerning prohibition order of public servant becoming political party member and official member. The regulation only arranging concerning public servant becoming member and official member of political party, while public servant which was nonmember of political party, what exactly more loyal in political party not yet been arranged in that regulation. The regulation which straightening of neutrality arrange in the preamble which public servant that impinge this regulation not yet arranged to collision, though sanction to this regulation was riffed as public servant, for public servant that becoming member and official member of political party.
\end{abstract}

Keyword: Neutralities, political party, law enforcement.

\section{A. Pendahuluan}

Pertanyaan mengenai ilmu hukum termasuk sebuah ilmu, dapat saja dikatakan sebagai pertanyaan contradictio in terminis, ini disebabkan banyak sekali pertentangan yang menyatakan bahwa hukum di satu sisi bersifat praktis dan di sisi lain bersifat teoritis. Pemahaman mengenai pengertian hukum itu sendiri sampai dengan saat ini sangat sulit di dapati, yang biasa dijadikan pengertian hukum adalah seperangkat kaidah yang bertujuan untuk mengatur tata kehidupan manusia.

Hukum yang merupakan seperangkat kaidah dinormatifkan ke dalam sebuah peraturan perundang-undangan, setiap peraturan perundang-undangan ini harus ditegakan dalam arti diimplementasikan agar dapat berlaku secara efektif.

Salah satu ranah hukum yang ada di Indonesia adalah hukum kepegawaian yang mengatur mengenai pegawai negeri itu sendiri, termasuk di dalamnya terkait dengan netralitas. Pelaksanaan netralitas pegawai negeri sampai saat ini masih terus menjadi perdebatan hangat, oleh sebab itulah perlu dikaji lebih mendalam mengenai netralitas dan penegakan hukumnya.

PNS diharapkan menjadi seorang yang profesional dalam menjalankan setiap tugas yang diembannya. Pandangan ini sesuai dengan kedudukan manusia, yaitu dengan ungkapan not the gun but the man behind the gun. Ungkapan ini sangat tepat diterapkan dalam membahas masalah kedudukan PNS. Kedudukan PNS diatur dalam Pasal 3 ayat (1) yang menyatakan bahwa:

(1) Pegawai Negeri berkedudukan sebagai unsur aparatur negara yang bertugas untuk memberikan pelayanan kepada masyarakat secara profesional, jujur, adil, dan merata dalam penyelenggaraan tugas negara, pemerintahan dan pembangunan.

(2) Dalam kedudukan dan tugas sebagaimana dimaksud dalam ayat (1), Pegawai Negeri harus netral dari pengaruh semua golongan dan partai politik serta tidak diskriminatif dalam memberikan pelayanan kepada masyarakat. 
(3) Untuk menjamin netralitas Pegawai Negeri sebagaimana dimaksud dalam ayat (2), Pegawai Negeri dilarang menjadi anggota dan/atau pengurus partai politik

Pengaturan ini mengindikasikan bahwa netralitas pegawai negeri dijamin dalam undang-undang agar pegawai negeri dapat melaksanakan tugasnya sesuai dengan ketentuan undang-undang. Ketentuan Pasal 3 UndangUndang No.43 Tahun 1999 itu kemudian diperjelas kembali pada Penjelasan Umum I angka 6 menyebutkan bahwa:

Dalam upaya menjaga netralitas Pegawai negeri dari pengaruh partai politik dan untuk menjamin keutuhan, kekompakkan dan persatuan Pegawai negeri serta dapat memusatkan segala perhatian, pikiran dan tenaganya pada tugas yang dibebankan kepadanya, maka Pegawai Negeri dilarang menjadi anggota dan/atau pengurus partai politik. Oleh karena itu, Pegawai Negeri yang menjadi anggota dan/atau pengurus partai politik harus diberhentikan sebagai pegawai negeri. Pemberhentian tersebut dapat dilakukan dengan hormat atau tidak dengan hormat.

Kedudukan PNS tersebut, menunjukan bahwa PNS merupakan tulang punggung bangsa dalam pelaksanaan pemerintahan dan pembangunan, serta melaksanakan birokrasi untuk melayani masyarakat. Kedudukan yang strategis ini diperlukan adanya PNS yang profesional. Untuk mencapai keprofesionalan ini pemerintah mengambil kebijakan, dengan mengeluarkan peraturan pemerintah tentang netralitas PNS, yaitu Peraturan Pemerintah Nomor 12 Tahun 1999 Tentang Perubahan Atas Peraturan Pemerintah Nomor 5 Tahun 1999 Tentang Pegawai Negeri Sipil Yang Menjadi Anggota Partai Politik kemudian diperbaharui kembali dengan Peraturan pemerintah No.37 Tahun 2004 dan aturan teknisnya dijelaskan melalui Surat Keputusan Badan Administrasi kepegawaian Negara (BAKN) No.02/BA/1999 tentang Pedoman Pelaksanaan Peraturan Pemerintah tersebut.

Netralitas PNS dalam partai politik merupakan kajian hukum kepegawaian. Kajian hukum kepegawaian mengatur pegawai negeri yang bekerja dalam administrasi negara. Hal ini sebagaimana dikemukakan oleh Utrech, yang menjelaskan bahwa hukum administrasi menguji hubungan hukum istimewa yang diadakan untuk memungkinkan para pejabat (amstragers) Administrasi negara melakukan tugas mereka yang khusus.

Keanggotaan dan kepengurusan dalam organisasi politik merupakan hak-hak dasar dan hak asasi manusia. Hak-hak dasar ini senantiasa merupakan hal yang menarik untuk selalu di kaji karena secara normatif dijamin dan dijunjumg tinggi. Masalah dasar dalam hak asasi manusia adalah masih adakah di dalam keterbatasaan terdapat kebebasan warga negara untuk turut serta berperan aktif dalam pemerintahan. ${ }^{1}$

Kebebasan untuk berserikat/berkumpul diatur pasal 28 UUD 1945 yaitu bahwa kemerdekaan berserikat dan berkumpul, mengeluarkan pikiran dengan lisan dan tulisan dan sebagainya ditetapkan dengan Undang-Undang. Peraturan pelaksana UUD ini adalah adanya organisasi kemasyara-katan dan organisasi politik

Ternyata, keikutsertaan Pegawai Negeri dalam dunia politik banyak menimbulkan perdebatan. Tuntutan agar Pegawai Negari Sipil netral dalam partai politik mulai bergema. Bahkan akhir-akhir ini gema tuntutan itu semakin didengungkan bersama dengan semakin kencangnya hembusan angin reformasi. Tuntutan agar Pegawai Negari Sipil netral dalam keanggotaan dan kepengurusan dalam partai politik adalah sesuatu yang wajar karena selama pada saat Orde Baru, KORPRI dijadikan sebagai mesin politik Golkar. Sedangkan keanggotaan Korpri sebagian besar adalah Pegawai Negari Sipil. Agar pengalaman yang pahit tersebut tidak terulang lagi, maka untuk menganti-sipasi hal ini Soewoto berpendapat bahwa peran Pegawai Negari Sipil yang memberikan kontribusi besar atas kemenangan

Sri Hartini, 2005, Netralitas Pegawai Negeri Sipil, Jakarta: Mahkamah Konstitusi, hlm. 24 
260 Jurnal Dinamika Hukum

Vol. 9 No. 3 September 2009

Golkar harus diantsipasi dengan Peraturan yang baru. $^{2}$

Pada era reformasi ini, keanggotaan dan kepengurusan Pegawai Negeri Sipil di dalam partai politik diatur tersendiri di dalam Peraturan Pemerintah No. 37 tahun 2004 tentang Larangan Pegawai Negari Sipil Menjadi Anggota Partai Politik. Peraturan perundang-undangan tersebut dibuat oleh pemerintah dengan tujuan agar Pegawai Negari Sipil bersikap netral. Sebab permasalahan yang selama ini terjadi adanya penggunaan fasilitas oleh birokrat/ Pegawai Negeri Sipil dalam partai politik tertentu. Latar belakang inilah yang dijadikan alasan bagi pemerintah untuk mengeluarkan peraturan tersebut .

PNS netral dalam partai politik memang sangat diperlukan untuk menyelesaikan permasalahan/konflik sepanjang orde baru. Namun setelah netralitas berjalan kurang lebih 10 (sepuluh) tahun, ternyata menimbulkan dampak positip dan negatif. Dampak positif, bahwa PNS tidak lagi disibukkan berkampanye, rapatrapat parpol, sehingga dapat melaksanakan pekerjaan secara optimal,

Dampak negatif yang muncul, adalah selama PNS, TNI, dan Polri, tidak ada keterwakilan dalam Dewan Perwakilan Rakyat Pusat maupun daerah. Dewan ini sering banyak menjadi sorotan masyarakat, seperti korupsi, perselingkuhan, ijazah palsu dan lain-lain. Apakah ini kebetulan masa reformasi ataukah ada hal lain yang perlu dibenahi kembali.

Pengaturan netralisas PNS, dalam Pasal 3 ayat (2) dan (3), serta PP No. 37 Tahun 2004, dalam pelaksanaanya menimbulkan permasalahan yang krusial, yang sampai saat ini belum mendapat perhatian dari semua kalangan. Permasalahan yang muncul yaitu, pengaturan baik dalam UU maupun aturan pelaksananya, hanya mengatur tentang larangan PNS yang menjadi anggota dan pengurus parpol. Bagaimana PNS yang tidak menjadi anggota dan pengurus tetapi kiprahnya melebihi anggota

\footnotetext{
Soewoto, Kebebasan Berserikat dan Berkumpul, Makalah Penataran Hukum Administrasi, diselenggarakan oleh Fakultas Hukum Universitas Airlangga bekerjasama dengan Utrecht Universiteit Belanda, 8 - 13 Februari 1999, hlm. 6
}

dan pengurus, wewenang siapa dalam menanganinya, prosedurnya bagaimana jika terjadi pelanggaran. Latar belakang ini yang akan menjadi kajian dalam tulisan ini.

Dari latar belakang tersebut di atas, dapat ditarik permasalahan berupa :

1. Bagaimanakah netralitas pegawai negeri sipil dalam partai politik?

2. Bagaimanakah penegakan hukum netralitas pegawai negeri dalam partai politik?

\section{B. Pembahasan}

Kebebasan dalam organisasi politik, merupakan konskuensi logis oleh hukum atau konstitusi atas hak-hak dasar dan hak asasi manusia dalam kehidupan kenegaraan. Kebebasan mengeluarkan pendapat dan pikiran merupakan indikasi bahwa suatu negara melaksanakan demokrasi Setiap negara yang mengaku negara hukum yang demokrastis harus memasukan aspek peran serta aktif rakyat di dalam konstitusinya yang dilandasi persamaan dan kemerdekaan/kebebasan. Kehidupan demokrasi di Indonesia, sebagaimana diatur Pasal 1 ayat (2) UUD 1945 yaitu "Kedaulatan adalah di tangan rakyat, dan dilakukan menurut Undang-Undang Dasar."

Kebebasan merupakan hak asasi manusia. Menurut Soewoto bahwa hak asasi itu bersifat universal, yang tidak universal adalah implementasinya dalam produk perundang-undangan. ${ }^{3}$ Jadi hak asasi manusia yang merupakan kebutuhan setiap manusia harus diatur dalam undang-undang suatu negara.

Kebebasan ini dipertegas lagi oleh Toto Pandoyo bahwa konsep kebebasan berserikat dan berkumpul ini merupakan bagian dari hak asasi manusia yang diakui secara yuridis baik internasional maupun nasional. ${ }^{4}$ Secara internasional diatur Article 20, Declaration of Human Rights sebagai berikut:

Soewoto, HAM Masalah Konsep, Penjabaran, Pelaksanaan dan Pengawasan di Indonesia, Makalah disampaikan dalam seminar sehari dan demokratisasi di Indonesia dalam rangka diesnatalis ke 31 Universitas Brawijaya 1 Februari 1994, hlm. 2.

4 Toto Pandoyo, 1981, Ulasan Terhadap Beberapa Ketentuan UUD 1945 dan Perkembangan Kehidupan Demokrasi, Liberty, Yogyakarta, hlm. 1. 
Everyone has the right to freedom of peaceful assembly and association no one may be compelled to belong an association.

Di Indonesia jaminan terhadap kebebasan berserikat dan berkumpul diatur pasal 28 UUD 1945. Sebagai realisasi kebebasan berserikat dalam partai politik adalah Undang-Undang No. 32 Tahun 2002 tentang Partai Politik, dalam penjelasan umum UU Partai Politik disebutkan bahwa pembentukan partai politik pada dasarnya merupakan suatu pencerminan hak warganegara untuk berserikat, berkumpul, dan menyatakan pendapat sesuai dengan pasal 28 UUD 1945. Partai politik merupakan sarana pendidikan politik warganegara untuk ikut berpartisipasi dalam kehidupan kenegaraan.

Fungsi undang-undang adalah mengatur baik warganegara maupun pemerintah. Hal ini sesuai dengan salah satu fungsi hukum adalah perlindungan hukum bagi rakyat dan mengatur kebebasan manusia secara wajar untuk menghindari bentrokan kepentingan yang satu dengan lainnya. Fungsi hukum yang memadai diharapkan dapat diciptakan dan dipelihara keamanan, ketertiban dan ketentraman dalam masyarakat.

Menurut Philipus M. Hardjon, bahwa undang-undang pada dasarnya dimaksudkan untuk membatasi kekuasaan pemerintah secara jelas dan tegas, di sisi lain dimaksudkan untuk melindungi hak-hak dasar. ${ }^{5}$ Jadi setiap pembatasan terhadap hak-hak dasar harus dengan instrumen undang-undang.

\section{Kebebasan Berserikat Pegawai Negeri Sipil dalam Peraturan Presiden No. 2 Tahun 1959}

PNS dalam partai politik merupakan masalah yang selalu tidak ada akhirnya. Hal ini sudah dimulai sejak masa Demokrasi liberal yaitu diatur dalam Peraturan Presiden (Perpres) No. 2 Tahun 1959 tentang larangan PNS dan Pejabat Negeri dalam Partai Politik. Perpres ini semula dikeluarkan untuk menyatukan PNS yang telah ter-pecah belah akibat permainan politik saat itu yang dikenal Nasakom. Perpres ini kemudian diikuti dan diperluas pula oleh Surat Edaran Presiden Republik Indonesia (SE) No. 2 Tahun 1959 tentang Larangan Keanggotaan Partai Politik bagi Pejabat Negari Jang Mendjalankan Kewadjiban Negara di Luar Djabatan Jang Dipangkunja.

Perpres ini menyatakan yang dimaksud Pejabat negeri menurut ketentuan pasal 1 ayat (1) adalah:

a. Pegawai pemerintah pusat yang digaji menurut atau berdasarkan golongan $\mathrm{F}$ dari PGPN-1955 dan pegawai pemerintah daerah yang digaji sesuai PGPN-1955;

b. Semua anggota angkatan perang dan Kepolisian Negara;

c. Anggota/direksi/pimpinan staf pada badanbadan usaha/yayasan-yayasan/perusahaanperusahaan/lembaga-lembaga baik yang secara langsung maupun tidak langsung seluruhnya atau sebagian dimiliki oleh negara.

Menyimak materi muatan Perpres No. 2 Tahun 1959 maupun Surat Edaran (SE) Presiden Republik Indonesia No. 2 Tahun 1959 penulis berkesimpulan bahwa Perpres ini membatasi kebebasan berpendapat sebagaimana tercantum dalam ketentuan Pasal 28 UUD 1945, bahkan kalau dikaji dengan konsep Hak Asasi Manusia bukan hanya sekedar membatasi bahkan tidak menjamin terhadap HAM yang bersifat universal.

Perpres No. 2 Tahun 1959 tentang larangan Pejabat Negeri ini telah dicabut berdasarkan Undang-Undang (UU) No. 2 Tahun 1970. Meskipun demikian Perpres tersebut merupakan tonggak penting dalam sejarah pengaturan PNS dalam partai politik. Perpres ini sebagai upaya pemerintah untuk memulihkan keadaan PNS pada saat itu berlarut-larut dalam permainan politik. Perpres ini pula diharapkan dapat memulihkan keutuhan dan kekompakan PNS. 
262 Jurnal Dinamika Hukum

Vol. 9 No. 3 September 2009

\section{Kebebasan Berserikat Pegawai Negeri Sipil dalam Peraturan Pemerintah No. 26 Tahun 1970}

Orde Baru merupakan masa pelaksanaan Pancasila secara murni dan konsekuen. Pelaksanaan ini meliputi segala bidang kehidupan. Masalah Pegawai Negeri merupakan agenda bagi Orde Baru. Orde Baru menyadari bahwa PNS harus diberi kesempatan untuk berserikat dalam partai politik. Atas dasar alsan tersebut di atas, diperlukan adanya pembinaan yang diatur dalam peraturan yang jelas. Hal inilah sebagai alasan untuk mengatur pegawai ngeri dalam suatu wadah yang berbentuk korp. Korp pegawai negeri ini dikenal dengan KORPRI dalam Keputusan Presiden No. 82 Tahun 1971 tentang Korpri.

Korpri merupakan wadah pegawai negeri sipil yang sangat strategis. Bahkan Korpri memberikan andil yang sangat besar pada pemerintahan Orde Baru. Untuk mempertahankan kondisi ini dikeluarkan be-berapa kebijakan yang berkaitan dengan Pegawai Negeri Sipil. Salah satu kebijakan yang dikeluarkan pemerintah adalah Peraturan Pemeritah No. 26 Tahun 1970 tentang Keanggotaan Pegawai Negeri Sipil dalam Partai Politik dan Golongan Karya. Esensi Peraturan Pemerintah khususnya Pasal 2 Peraturan Pemerintah ini berkaitan dengan Izin Bagi Pegawai Negeri Sipil dalam partai politik. Politik hukum tentang pemberian izin PNS dalam Partai Politik adalah adanya usaha merekrut PNS untuk memperkuat kekuatan pemerintahan ORBA. Hal ini dinyatakan oleh Afan Gafar: ${ }^{6}$

Birokrasi dalam pemerintahan Orde Baru merupakan sebuah instrumen politik yang sangat efektif dalam memobilisasi masa demi memelihara format politik Orde Baru. Kehadiran birokrasi sebagai instrumen kekuasaan salah satunya diwujudkan memberi dukungan langsung kepada Golkar pada setiap kali pemilihan umum.

Dukungan ini lebih diperkuat lagi dalam UU. No. 3 Tahun 1985 tentang Partai Politik

\footnotetext{
Afan Gafar, 1999., Politik Indonesia Transisi Menuju
} Demokrasi, Yogyakarta: Pustaka Pelajar, hlm. 235-237 dan Golongan Karya, pasal 8 ayat (2) yang menyatakan bahwa :

a. PNS dapat menjadi anggota partai politik dan Golongan Karya dengan sepengetahuan pejabat yang berwenang;

b. PNS yang memegang jabatan-jabatan tertentu tidak dapat menjadi anggota partai politik dan golongan karya, kecuali dengan izin tertulis dari pejabat yang berwenang.

Ketentuan pasal 8 tersebut di atas secara normatif memberi kebebasan PNS menjadi anggota dan pengurus partai politik, namun secara realitias izin tersebut menjadi permasalahan hukum tersendiri. Pemberian izin selalu tidak transparan. Hal ini mengakibatkan banyak PNS yang dirugikan dengan alasan izin.

Pemberian izin inilah pada masa Orde Baru disalahgunakan dengan alasan mengganggu pelaksanaan tugas. Apabila pejabat konsisten, PNS yang menjadi anggota dan pengurus Organisasi Kemasyarakatanpun seharusnya juga dilarang karena dapat mengganggu pelaksanaan tugas. Melihat realitas ini, pemerintah Orde Baru dalam pemberian izin tidak konsisten. Selain alasan tersebut pada masa Orde Baru PNS dalam partai politik selalu dikaitkan dengan monoloyalitas. Monoloyalitas sangat positif jika dilaksanakan dengan konsisten sesuai dengan UU No.8 1974 tentang Pokokpokok Kepegawaian khususnya pasal 3. Maksud monoloyalitas pasal 3 tersebut adalah PNS untuk kepentingan pemerintah, namun realitasnya digunakan untuk mendukung golongan/ partai tertentu yaitu dijadikan motor penggerak kemenangan Golkar melalui KORPRI.

Hal ini seperti dinyatakan oleh Afan Gafar bahwa: ${ }^{7}$

Kehadiran birokrasi sebagai instrumen kekuasaan dapat diwujudkan dalam bentuk memberi dukungan langsung kepada Golongan Karya pada setiap kali pemilihan umum diadakan. Pada pemilihan umum 1977, PNS memberikan suaranya buat Golkar. Kalau itu kemudian ditambah dengan suara dari keluarga, seperti suami/istri, atau anak yang sudah berhak memilih, Golkar akan mendapat sekitar

Ibid., hlm. 235 
10 juta suara dari PNS dan keluarganya. Dengan demikian PNS menyumbang suara yang sangat berarti bagi Golkar.

Atas dasar uraian di atas penulis simpulkan bahwa pegawai negeri sipil pada masa Orde Baru meskipun membatasi PNS dalam partai politik, namun secara normatif masih memberi kesempatan PNS dalam partai politik. Ini merupakan politik hukum yang digunakan dan dilegalkan oleh pemerintah agar PNS sebagai abdi negara harus menuruti kemauan penguasa. Ketentuan tersebut dapat dilihat bahwa peranan PNS tidak lagi secara nyata sebagai aparatur negara, abdi negara dan abdi masyarakat, sebagai alat dalam mencapai kemenangan Golkar setiap pemilihan umum, dan hal ini berlaku sampai pemilu tahun 1997.

\section{Netralitas Pegawai Negeri Sipil pada Era Reformasi}

Keadaan Pegawai Negeri pada masa Orde Baru yaitu 11 Maret 1966 sampai dengan 21 Mei 1998, yang dijadikan alasan era reformasi untuk segera membenahi peraturan tentang keikut sertaan PNS dalam partai politik. Hal ini dimulai dari Pengunduran diri Soeharto sebagai Presiden tanggal 21 Mei 1998 merupakan tonggak baru dalam kehidupan pemerintahan di Indonesia. Bersamaan dengan itu, hembusan angin reformasi yang berkaitan dengan partai politik dijadikan agenda utama. Pada masa reformasi, hal yang berkaitan dengan PNS dalam partai politikpun menjadi hangat dibicarakan akhirnya timbullh kebijakan tentang netralitas PNS.

Selama ini, PNS menjadi perdebatan dalam kehidupan demokrasi di Indonesia. Peraturan Pemerintah No. 5 Tahun 1999 jo Peraturan Pemerintah No. 12 Tahun 1999 dan terakhir dengan Peraturan pemerintah No.37 tahun 2004 tentang Larangan PNS menjadi Anggota Partai Politik ini di-maksudkan untuk menjawab permasalahan yang selama ini terjadi. Peraturan tersebut dimaksudkan PNS netral dalam partai politik. Peraturan ini pula diharapkan dapat memberi angin segar dalam kehidupan partai politik di Indonesia karena selama ini PNS digunakan guna mendukung salah satu partai politik saja. Adanya peraturan ini diharapkan kehidupan berpolitik di Indonesia akan lebih demokratis tanpa diwarnai rasa saling curiga. ${ }^{8}$

Akibat permainan politik yang dilakukan pada Orde Baru tentang pegawai negeri dalam partai politik mengakibatkan ketidakseimbangan dalam perolehan suara setiap pemilu. Bahkan ini merupakan sumber konflik dalam partai politik. Kabinet Reformasi Pemerintah Habibie berupaya akan melakukan reformasi di segala bidang, dalam rangka reformasi politik menuju kehidupan politik yang lebih demokratis. Upaya tersebut guna menciptakan pemerintahan yang baik, berwibawa dan bersih, termasuk di dalamnya tentang kedudukan Pegawai Negeri Sipil dalam kehidupan partai politik sudah saat-nya ditinjau kembali. ${ }^{9}$ Keinginan reformasi Pegawai Negeri Sipil dalam partai politik ini disebabkan Adanya pegawai negeri yang dijadikan alat politik golkar tersebut, meng-akibatkan fungsi PNS/birokrasi itu akan terganggu. Sebab setiap birokrasi dalam pembentukan dan perwujudan kebijaksanaan publik adalah sebagai "implementing agency" yaitu menghantarkan kebijaksanana publik itu ke masyarakat.

Atas dasar dan kenyataan masa Orde Baru ini, seyogyanya PNS itu Netral. Penulis setuju bahwa PNS untuk saat ini harus netral. Netralitas PNS dalam partai politik memang untuk saat ini sangat diperlukan. Hal ini seperti dinyatakan oleh Mahfud bahwa:

Salah satu persoalan besar bangsa ini dalam kehidupan bernegara adalah persoalan netralitas pegawai negeri karena secara teoritis sulit ditemukan landasan teoritis yang dapat mem-berikan alasan pembenar bagi dimungkinkannya pegawai negeri untuk terlibat dalam kegiatankegiatan politik praktis. ${ }^{10}$

Akibat penyelewengan yang dilakukan itu, tuntutan agar Pegawai Negeri Sipil netral

\footnotetext{
Sri Hartini, 2000, Kebebasan Berserikat Pegawai Negeri Sipil Dalam Partai Politik. Tesis. Surabaya: Universitas Airlangga, hlm. 54

9 Sri Hartini, 2005, Nop.cit., hlm.1

10 Mahfud. MD, 1988, Pergulatan Politik dan Hukum di Indonesia, Yogyakarta: Gema Media, hlm. 69.
} 
dalam partai politik dalam keanggotaan dan kepengurusan dalam partai politik adalah wajar. Karena selama Orde Baru KORPRI dijadikan mesin politik Golkar. Sedangkan keanggotaan KORPRI sebagian besar adalah Pegawai Negeri Sipil.

Jadi netralitas pegawai negeri diperlukan sepanjang sifatnya hanya sementara dan selama masa transisi, bukan bersifat langgeng untuk jangka waktu yang panjang. Karena apabila berlangsung lama mengkibatkan hilangnya kebebasan berserikat bagi pegawai negeri sipil. Dengan demikian netralitas pegawa negeri diperlukan hanya untuk menyelesaikan konflik yang terjadi selama Orde Baru.

Netralitas PNS yang sudah berjalan selama 10 tahun, perlu direnungkan kembali, konsekensi terhadap kualitas, moralitas, pengalaman anggota dewan . Anggota dewan adalah wakil rakyat yang akan menjadikan negara ini kearah mana, sehingga diharapkan anggota dewan syarat dengan nama besar tersebut.

Netralitas diharapkan untuk perbaikan untuk masa mendatang. Dalam mengkaji netralitas, dibatasi dalam pengertian sebagaimana tertuang dalam Peraturan Pe-merintah No. 5 Tahun 1998 yang kemudian dirubah dengan Peraturan Pemerintah No. 12 Tahun 1998, yang sekarang diatur dalam Peraturan Pemerintah No. 37 Tahun 2004 tentang Larangan Pegawai Negeri Sipil yang menjadi anggota Partai Politik. Netralitas diatur pasal 3 adalah:

Dalam kedudukan sebagaimana dimak-sud dalam pasal 2, pegawai negeri sipil harus bersikap netral dan menghindari fasilitas negara.

Selanjutnya Netralitas ini juga dimaksudkan Pasal 4 adalah:

Pegawai negeri sipil dalam menyelenggarakan tugas pemerintah dan pembangunan sebagaimana dimaksud dalam pasal 2 tidak diskriminatif khususnya dalam memberikan pelayanan kepada masyarakat.

Menurut Marbun makna netralitas adalah :

Bebasnya Pegawai Negeri Sipil dari pengaruh kepentingan partai politik terten- tu atau tidak memihak untuk kepentingan partai tertentu atau tidak berperan dalam proses politik. Namun Pegawai Negeri Sipil masih tetap mempunyai hak politik untuk memilih, dan berhak untuk dipilih dalma pemilihan umum. Namun tidak diperkenankan aktif menjadi anggota dan pengurus partai

Maksud netralitas yang lain adalah jika seorang Pegawai Negeri Sipil aktif menjadi pengurus partai politik atau anggota legislatif, maka ia harus mengundurkan diri. Dengan demikian birokrasi pemerintahan akan stabil dan dapat berperan mendukung serta merealisasikan kebijakan atau kehendak politik manapun yang sedang berkuasa dalam pemerintahan. ${ }^{11}$

Makna netralitas tersebut di atas adalah bebasnya Pegawai Negeri Sipil dari pengaruh kepentingan partai politik tertentu atau tidak memihak untuk kepentingan partai tertentu atau tidak berperan dalam proses politik karena dikhawatirkan pegawai tersebut menyalahgunakan penggunaan fasilitas negara untuk kepentingan partai seperti yang telah terjadi pada masa Orde Baru. Jadi tidak ada larangan keterwakilan pegawai negeri dalam Lembaga perwakilan rakyat.

Netralitas, seyogyanya tidak dikaitkan dengan keterwakilan Pegawai negeri di dalam anggota Dewan. Sejarah membuktikan bahwa, pegawai negeri merupakan orang karier yang berpengalaman, bekerja tanpa imbalan yang menggiurkan sesuai dengan perannya, yang masih memikirkan kehormatan dirinya, untuk keluarga, masyarakat dan tugas-tugasnya, sehingga apabila pegawai negeri selesai menjalankan tugasnya sebagai dewan. Mereka masih berharap kembali menjadi seorang yang disegani dan dihormati, bahkan waktu berjalan juga menunjukkan jarang pegawai negeri terlibat skandal, korupsi ini menunjukan budaya malu masih sangat dijunjung tinggi

Dengan demikian netralitas Pegawai negeri, adalah tidak melarang pegawai negeri

\footnotetext{
11 S.F.Marbun, 1998, Reformasi Hukum Tata Negara, Netralitas Pegawai Negeri dalam Kehidupan Politik di Indonesia, Yogyakarta: Fakultas Hukum Universitas Islam Indonesia, hlm. 74.
} 
duduk di anggota Dewan, yang bukan dari partai politik melalui perwakilan. Data tersebut di atas juga didukung oleh data yang lain bahwa seseorang yang mendapat kesempatan belajar, seorang yang mempunyai karier untuk mengembangkan pe-ngetahuannya, dan masih selalu memper-hatikan terhadap etika, rasa malu jika melakukan pelanggaran adalah Pegawai Negeri baik PNS, POLRI, maupun TNI, sehingga netralitas Pegawai negeri memang diperlukan. Jadi netralitas PNS tidak termasuk dalam larangan keterwakilan PNS dalam anggota Dewan. Apalagi menyimak kondisi anggota dewan yang akhir-akhir ini menjadi sorotan publik terhadap etika anggota dewan .

\section{Penegakan hukum netralitas PNS dalam partai politik}

Secara normatif Penegakan hukum netralitas hanya berlaku bagi PNS yang melanggar ketentuan UU No. 43 Pasal 3 ayat (2) dan (3) adalah serangkaian upaya yang dilakukan pemerintah untuk memberlakukan suatu peraturan perundang-undangan secara benar sesuai dengan norma yang telah ditetapkan. Penegakan hukum itu sendiri terbagi menjadi beberapa proses yaitu perumusan, pengesahan (penormaan), dan pengaplikasian norma yang telah dirumuskan.

Penegakan hukum yang terkait dengan netralitas pegawai negeri adalah penegakan hukum yang berkaitan dengan tugas dan wewenang serta kedudukan seorang pegawai negeri itu sendiri. Pegawai negeri yang dimaksud adalah pegawai negeri dalam rumusan Pasal 1 angka 1 Undang-Undang No.43 Tahun 1999 Tentang Perubahan Atas Un-dang-Undang No. 8 Tahun 1974 Tentang Pokok-pokok Kepegawaian, yaitu sebagai berikut :

Pegawai Negeri adalah setiap warga negara Republik Indonesia yang telah memenuhi syarat yang ditentukan, diangkat oleh pejabat yang berwenang dan diserahi tugas dalam suatu jabatan negeri, atau diserahi tugas negara lainnya, dan digaji berdasarkan peraturan perundang-undangan yang berlaku.
Di dalam Pasal 2 Undang-Undang No. 43 Tahun 1999 diatur bahwa :

Pasal 2

(1) Pegawai Negeri terdiri dari :

a. Pegawai Negeri Sipil;

b. Anggota Tentara Nasional Indonesia

c. Anggota Kepolisian Negara Republik Indonesia.

(2) Pegawai Negeri Sipil sebagaimana dimaksud dalam ayat (1) huruf a, terdiri dari :

a. Pegawai negeri Sipil Pusat; dan

b. Pegawai Negeri Sipil Daerah.

Pasal 2 Undang-Undang No.43 Tahun 1999 mengisyaratkan bahwa pegawai negeri terdiri dari sipil dan anggota TNI serta anggota kepolisian yang kesemuanya harus netral dalam menjalankan tugas, tanggung jawab dan wewenangnya, Penegakan ini belum diatur bagimana jika pelenggaran dilakukan oleh PNS yang bukan anggota dan Pengurus tetapi mereka lebih aktif, me-rupakan wewenang siapa, dan bagaimana prosedur di dalam peraturan netralitas tersebut ternyata belum mengatur

Penjelasan Umum I angka 6 UndangUndang No.43 Tahun 1999 mengindikasikan bahwa sanksi bagi pegawai negeri yang tidak netral secara normatifkan dikenakan sanksi yaitu pemberhentian sebagai pegawai negeri baik secara hormat maupun secara tidak hormat. Pemberhentian pegawai negeri sipil ini didasarkan pada Peraturan Pemerintah No.32 Tahun 1976 Tentang Pemberhentian Pegawai Negeri Sipil Republik Indonesia. Secara normatif, penegakan hukum netralitas pegawai negeri tidaklah bermasalah namun dalam realisasinya penegakan hukum ini dipengaruhi oleh banyak faktor di luar hukum.

\section{Penutup}

1. Simpulan

Netralitas PNS, merupakan solusi untuk menyelesaikan permasalahan tentang keikutsertaan PNS dalam partai politik, yang selama orde baru dijadikan permainan politik oleh pemerintah yang berkuasa. Pengaturan netralitas PNS, dalam Peraturan perundang-undangan, 
yaitu UU No. 43 Tahun 1999 Pasal 3 ayat (2) dan ayat (3) dan Peraturan Pemerintah No. 37 Tahun 2004 tentang Larangan Pegawai Negeri Sipil yang menjadi anggota Partai Politik.

Pengaturan Netralitas Pegawai Negeri Sipil tersebut harus mampu menyelesaikan konflik yang terjadi selama Orde Baru, sehingga diharapkan dengan adanya netralitas Pegawai ini akan memperbaiki kekurangan-kekurang anggota legislatif pada masa sebelumnya, bukan sebaliknya dan menimbulkan permasahan baru. Lembaga legislatif merupakan lembaga terhormat yang menyalurkan aspirasi masyarakat untuk menyejahterakan masyarakat, bukan ajang mencari nafkah, sehingga dapat dibeli, dan jangan meninggalkan kwalitas dan moralitas, anggota dewan harus menjadi orang yang menjadi panutan dan contoh tauladan baik di dinas maupun di luar dinas bagi masyarakat. Dengan peraturan netralitas pemerintah harus mampu merealisasikan peraturan tersebut, Dengan demikian tujuan netralitas akan dapat tercapai.

Penegakan hukum terhadap netralitas PNS, dalam realisasinya mengalami kesulitan, karena Pengaturan mengenai penegakan hukum netralitas pegawai negeri yang diatur dalam Undang-Undang No.43 Tahun 1999 Tentang Perubahan Atas Undang-Undang No. 8 Tahun 1974 Tentang Pokok-Pokok Kepegawaian, yaitu Pasal 3 dan Penjelasan Umum I angka 6, memberi sanksi bagi PNS yang melanggar peraturan ini diberhentikan dari PNS, Peraturan ini hanya mengatur bagi PNS yang menjadi anggota dan pengurus parpol, sehingga peraturan tersebut belum dapat menyelesaikan setiap pelanggaran tentang netralitas. Jadi bagi PNS yang tidak menjadi anggota dan pengurus parpol, mereka lebih loyal, justru lepas dari sanksi.

\section{Saran}

Peraturan tentang Netralitas hendaknya di tinjau kembali, karena ada peluang PNS untuk melakukan pelanggaran terhadap peraturan, yaitu PNS yang tidak menjadi anggota maupun pengurus tetap loyal dalam partai politik, namun tidak dapat di kenakan sanksi.
Netralitas PNS dalam partai politik memang diperlukan, Namun dalam Keanggotaan anggota Dewan, hendaknya melibatkan keterwakilan dari PNS, TNI dan POLRI, melalui penunjukkan, sehingga akan mewarnai kehidupan yang lebih demokratis

\section{Daftar Pustaka}

\section{Buku Literature}

Gafar, Afan, 1999. Politik Indonesia Transisi Menuju Demokrasi. Yogyakarta: Pustaka Pelajar;

Hadjon, Philipus M., Perlindungan Hukum dalam Negara Pancasila, Makalah simposium tentang Politik Hak Asasi Manusia dan Pembangunan Hukum, dalam Rangka Dies Natalis XL/Lustrum Universitas Airlangga, Surabaya 3 November 1994;

Hartini, Sri, Setiajeng K dan Tedi S. 2008. Hukum Kepegawaian Indonesia, Jakarta: Sinar Grafika;

Kadarsih, Setiajeng, dan Sri Hartini. 2005. Makalah Netralitas Pegawai Negeri Sipil, Jakarta: Mahkamah Konstitusi;

M.D., Mahfud. 1988. Pergulatan Politik dan Hukum di Indonesia. Yogyakarta: Gema Media

Marbun, S.F.1998. Reformasi Hukum Tata Negara", Netralitas Pegawai Negeri dalam Kehidupan Politik di Indonesia. Yogyakarta: Fakultas Hukum Universitas Islam Indonesia;

Muchsan.1982. Hukum Kepegawaian. Jakarta: Bina Aksara;

Pandoyo, Toto. 1981. Ulasan Terhadap Beberapa Ketentuan UUD 1945 dan Perkembangan Kehidupan Demokrasi, Yogyakarta: Liberty;

Soewoto, Kebebasan Berserikat dan Berkumpul, Makalah Penataran Hukum Administrasi, diselenggarakan oleh Fakultas Hukum Universitas Airlangga bekerjasama dengan Utrecht Universiteit Belanda, 8 13 Februari 1999;

Wijaya, A.W. 1986. Administrasi kepegawaian Suatu Pengantar. Jakarta: CV. Rajawali. 


\section{Peraturan Perundangan}

UU No. 43 tahun 1999 tentang Perubahan atas UU No. 8 Tahun 1974 tentang PokokPokok Kepegawaian

Peraturan Pemerintah No. 37 Tahun 2004 tentang Larangan Pegawai Negeri Sipil yang menjadi anggota Partai Politik. Netralitas

Peraturan Pemerintah No.32 Tahun 1979 Tentang Pemberhentian Pegawai Negeri Sipil Republik Indonesia 